\title{
LENKE 1 AND 5: CHANGES IN SAGITTAL BALANCE
}

\author{
LENKE 1 E 5: ALTERAÇÕES DO EQUILÍBRIO SAGITAL
}

LENKE 1 Y 5: CAMBIOS DEL EQUILIBRIO SAGITAL

Delson Valdemir Pessin ${ }^{1}$, José Osni Bruggemann Neto ${ }^{1}$, Carlos Henrique Maçaneiro', Ricardo Kiyoshi Miyamoto',

Rodrigo Fetter Lauffer ${ }^{1}$, Ricardo Acácio dos Santos ${ }^{1}$

\begin{abstract}
Objective: To assess in a cross-sectional study whether there are changes in sagittal balance in patients with adolescent idiopathic scoliosis Lenke types 1 and 5 compared with patients without pathology of the spine and compare the values of the parameters of normal subjects with the parameters found in the literature. Methods: We measured the values of the parameters of sagittal balance of 21 patients with scoliosis and 14 patients without scoliosis in panoramic radiographs or simply collected data previously measured from the medical records. We compared the mean values of normal subjects, the mean values found in the literature, and the means between normal subjects and patients with scoliosis. For this, we used the Student t test. Results: Using a confidence interval of $5 \%(p<0.05)$ and the Student t test we obtained statistical significance in the comparison of two parameters of sagittal balance between normal subjects and patients with scoliosis. We observed similarities in the measurements of the average parameters of normal subjects with regard to the work already published. Conclusions: The adolescent idiopathic scoliosis causes changes in two parameters of sagittal balance with statistical significance but suggests changes in all other parameters. As for comparison with previously published work, the results were similar.
\end{abstract}

Keywords: Scoliosis; Spinal curvatures; Posture.

\section{RESUMO}

Objetivo: Avaliar transversalmente se há alteração no equilíbrio sagital dos pacientes com escoliose idiopática do adolescente Lenke tipos 1 e 5 com relação aos pacientes sem patologia de coluna e comparar os valores dos parâmetros de indivíduos normais e os parâmetros encontrados na literatura. Métodos: Aferimos os valores dos parâmetros do equilíbrio sagital de 21 pacientes com escoliose e 14 pacientes sem escoliose em radiografias panorâmicas ou simplesmente coletamos os dados aferidos previamente do prontuário médico. Fizemos a comparação das médias dos valores dos pacientes normais com as médias dos valores encontrados na literatura e a comparação das médias entre os pacientes normais e os pacientes com escoliose. Para tanto, utilizamos o teste $t$ de Student. Resultados: Utilizando um intervalo de confiança de 5\% ( $p<0,05)$ e o teste t de Student, obtivemos significância estatística na comparação de dois parâmetros do equilíbrio sagital entre os pacientes normais e os pacientes com escoliose. Verificamos semelhanças nas aferições das médias dos parâmetros dos pacientes normais com relação a trabalho já publicado. Conclusões: A escoliose idiopática do adolescente causa alterações em dois parâmetros do equilíbrio sagital com significância estatística, mas sugere alterações em todos os demais parâmetros. Quanto à comparação com trabalho já publicado, houve semelhança nos resultados.

Descritores: Escoliose; Curvaturas da coluna vertebral; Postura.

\section{RESUMEN}

Objetivo: Evaluar en un estudio transversal si hay cambios en el equilibrio sagital en pacientes con escoliosis idiopática del adolescente tipos Lenke 1 y 5 en comparación con los pacientes sin patología de la columna vertebral y comparar los valores de los parámetros de los sujetos normales con los parámetros encontrados en la literatura. Métodos: Se midieron los valores de los parámetros de equilibrio sagital de 21 pacientes con escoliosis y 14 pacientes sin escoliosis en radiografías panorámicas o simplemente se recolectaron datos medidos previamente de los registros médicos. Se compararon los valores medios en los sujetos normales, los valores medios encontrados en la literatura, y las medias entre sujetos normales y pacientes con escoliosis. Para eso se utilizó la prueba t de Student. Resultados: Utilizando un intervalo de confianza del $5 \%(p<0,05)$ y la prueba t de Student se obtuvo significación estadística en la comparación de los dos parámetros de equilibrio sagital entre los sujetos normales y los pacientes con escoliosis. Hemos observado similitudes en las mediciones de los parámetros promedio de sujetos normales con respecto a la obra ya publicada. Conclusiones: La escoliosis idiopática del adolescente provoca cambios en dos parámetros de equilibrio sagital con significación estadística, pero sugiere cambios en todos los otros parámetros. En cuanto a la comparación con trabajos publicados anteriormente, los resultados fueron similares.

Descriptores: Escoliosis; Curvaturas de la Columna Vertebral; Postura.

\section{INTRODUCTION}

The objective of studying sagittal balance is to evaluate the global, regional, and local parameters of the axial skeleton and pelvis. To access global balance, which is the alignment of the spine as a whole, the center of $\mathrm{C} 7$ and the sacrum or pelvis are used as proximal and distal references, respectively. There is a correlation between the pelvic, lumbar, thoracic, and cervical parameters in maintaining the individual erect. ${ }^{1-9}$ Some pathologies, such as scoliosis, can cause changes to these parameters, resulting in changes in sagittal balance and in the individual's energy expenditure. ${ }^{10}$

Adolescent idiopathic scoliosis (AIS) is a classic orthopedic problem of unresolved cause, characterized by deformity of the sagittal (thoracic lordosis), frontal (lateral curve), and transversal (vertebral rotation) planes of the spine. ${ }^{11}$ The Lenke classification, with six curve patterns and their sagittal and lumbar modifiers, is one of the most commonly used for AIS, and provides us with criteria for surgical planning. ${ }^{12}$

The objective of this study is to assess whether scoliosis causes

1. Instituto de Ortopedia eTraumatologia de Joinville, Joinville, SC, Brazil. 
changes in the following sagittal balance parameters: lumbar lordosis $(\mathrm{L}(\mathrm{L} 1-\mathrm{S} 1))$, thoracic kyphosis $(\mathrm{K}(\mathrm{T} 2-\mathrm{T} 5))$, plumb line $(\mathrm{PL})$, pelvic incidence (PI), sacral slope (SS), pelvic tilt (PT), S1 projection (SP), spino-sacral angle (SSA), and spinal inclination (SI) in Lenke's curve types 1 and 5 . The values found in this study will be compared with the scientific study by Mac-Thiong et al. ${ }^{13}$ (Figure 1)

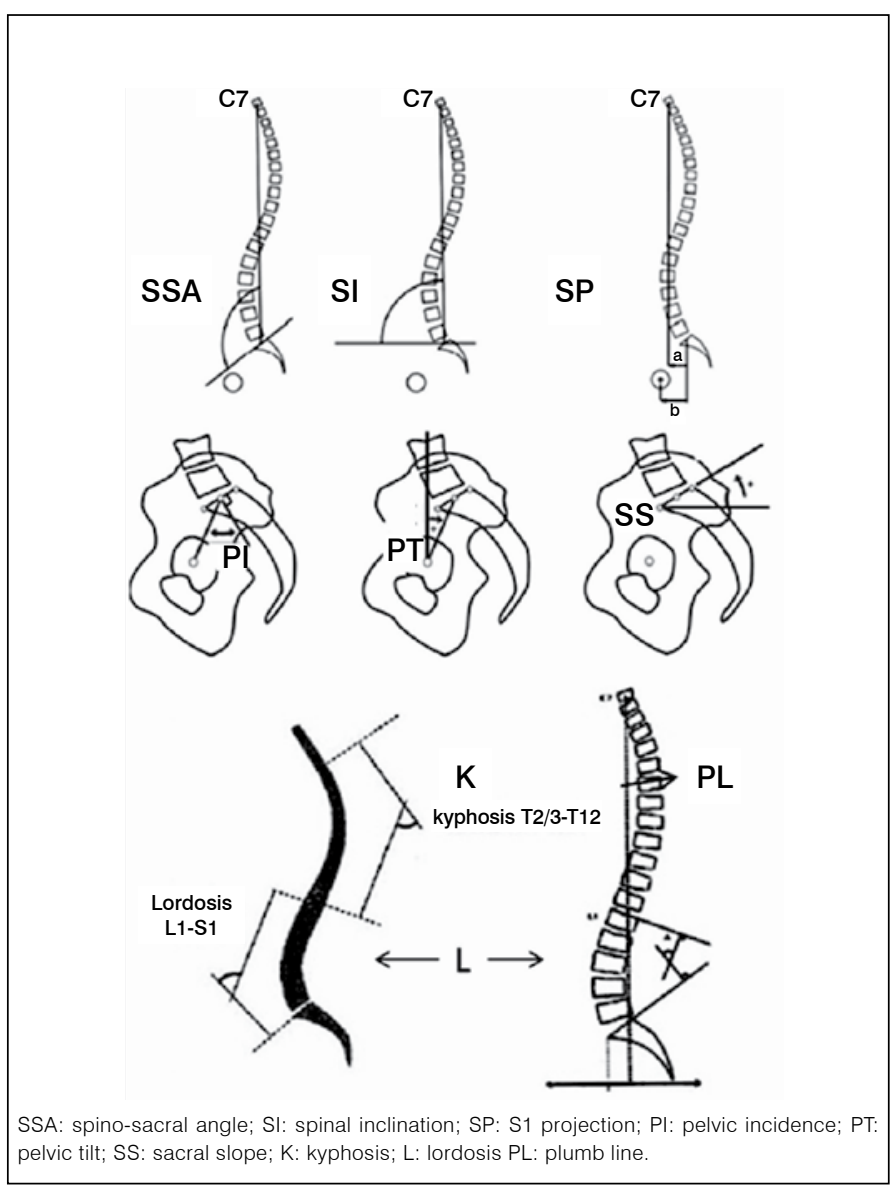

Figure 1. Sagittal balance parameters.

\section{METHODS}

Once the project had been evaluated and approved by the Ethics Committee, the informed consent and confidentiality forms were duly signed and filed.

A cross-section of patients in follow-up and treatment for AIS by the Spine Surgery Group of the Instituto de Ortopedia e Traumatologia de Joinville, Joinville, SC, Brazil, was selected and their medical records and radiographs taken during treatment were evaluated. Patients aged between 10 and 18 years, with a diagnosis of AIS classified into Lenke groups 1 and 5, who had not used a brace vest or whose last radiograph was taken prior to using the vest and dated while the patient was between 10 and 18 years of age, were included. Other types of scoliosis and AIS classified as Lenke types 2, 3, 4, and 6 were not included.

The sagittal balance parameters were then measured using panoramic profile view radiographs of the spine from the $\mathrm{C} 7$ vertebral body to the femoral heads, essential for its tracing. In cases where medical records were available, these were collected without further investigation of the x-rays. A group of 21 patients treated between 2010 and 2012 was obtained. Radiographs of 14 patients between 7 and 38 years of age, with the same specifications as those cited above and without any pathology, were used for the comparison. The averages of each sagittal balance parameter were compared between the patients with AIS and the patients without spinal pathology.

For the statistical analysis, a significance level of $5 \%$ was adop- ted, $a=0.05$, using the Student's $t$-test for comparison, as the null hypothesis $(\mathrm{H} \otimes)$ that there would be no difference between the averages of the samples, and as the alternate hypothesis $(\mathrm{HA})$ that there would be a difference between the average sample values with a statistical significance of $5 \%$. A calculated significance $(p)$ less than $0.05(p<0.05)$ for a parameter would refute $\mathrm{H}_{\boldsymbol{\alpha}}$ and $\mathrm{HA}$ would be accepted, indicating that scoliosis would cause a change in this sagittal balance parameter. Otherwise, $\mathrm{H}_{\boldsymbol{\alpha}}$ would be accepted and there would be no statistical difference between the samples. The age and sex of the patients was not considered in the statistical calculation. Regarding the study of Mac-Thiong et al, ${ }^{13}$ only the statistical similarity between the averages of the results was evaluated. The data for the patients of two surgeons was collected by two resident doctors in spine surgery.

\section{RESULTS}

The results obtained demonstrate statistical significance in two of the parameters analyzed, PT and SS $(p<0.05)$. Table 1 shows examples of the graphs of the dispersion between the average of the pelvic parameters, $\mathrm{PI}, \mathrm{PT}$, and SS, between patients with scoliosis and normal individuals. Although the other variables do not show statistical significance in the Student's t-test, a considerable increase in all the averages of the sagittal balance parameters can be observed by studying the graphs of the variables, suggesting that scoliosis causes changes in all these parameters. (Figure 2)

The data collected from the 14 normal individuals yielded results similar to the normal values cited in the study by Mac-Thiong et al. ${ }^{13}$ (Table 2)

Table 1. Correlation of the sagittal balance parameters between patients with and without scoliosis.

\begin{tabular}{c|c}
\hline Parameters & $\mathbf{P}$ \\
\hline $\mathrm{PI}$ & 0.06 \\
\hline $\mathrm{PT}$ & $0.03^{\circledR}$ \\
\hline SS & $0.03^{\circledR}$ \\
\hline SSA & 0.12 \\
\hline $\mathrm{SI}$ & 0.07 \\
\hline $\mathrm{SP}$ & 0.08 \\
\hline $\mathrm{L}$ & 0.17 \\
\hline $\mathrm{K}$ & 0.60 \\
\hline $\mathrm{PL}$ & 0.20 \\
\hline Statistical significance & $\mathrm{P}<0.05$
\end{tabular}

\section{DISCUSSION}

Even with the large difference in the number of normal individuals, 14 versus 709 in the study of Mac-Thiong et al, ${ }^{13}$ this study showed a similarity in the results obtained. (Table 2) The major differences found, PT (7.1 vs. 13.05) and SP (4.3 vs. 0.1), are due to the wide dispersion presented by several individuals. Because the $n$ of the study in question is small, even a single change can cause a great discrepancy in the results. This may be due to a poorly taken radiograph or even to an evaluation error. Even with the differences found between the two parameters, the comparison with individuals who have scoliosis demonstrates that the pathology causes changes in two sagittal balance parameters, and suggests that it causes changes in all the parameters. Mac-Thiong et $\mathrm{a}^{13}$ did not consider lordosis and kyphosis in their study and the PL was divided into six types, depending upon the location of the center of the femoral heads in relationship to the center of the superior plateau of S1. In this study, all the subjects were types 1 and 2. A continuation of this study including individuals of all PL types defined by Mac-Thiong et a ${ }^{13}$ could provide us with a better evaluation of the parameter and the changes in the pathology in question.

The study of Roussouly et al, ${ }^{14}$ which evaluated and compared pre- and postoperative sagittal balance in adolescent and adult patients with AIS, demonstrated that prior to surgery, regardless of the value of PI, PT remains anteverted or normal, while PL was more variable, $50 \%$ behind the femoral heads. The thoracic kyphosis values were below average and the lumbar lordosis values remained within normal ranges. Our study demonstrated an increase in kyphosis in patients with scoliosis as compared to patients without spinal pa- 


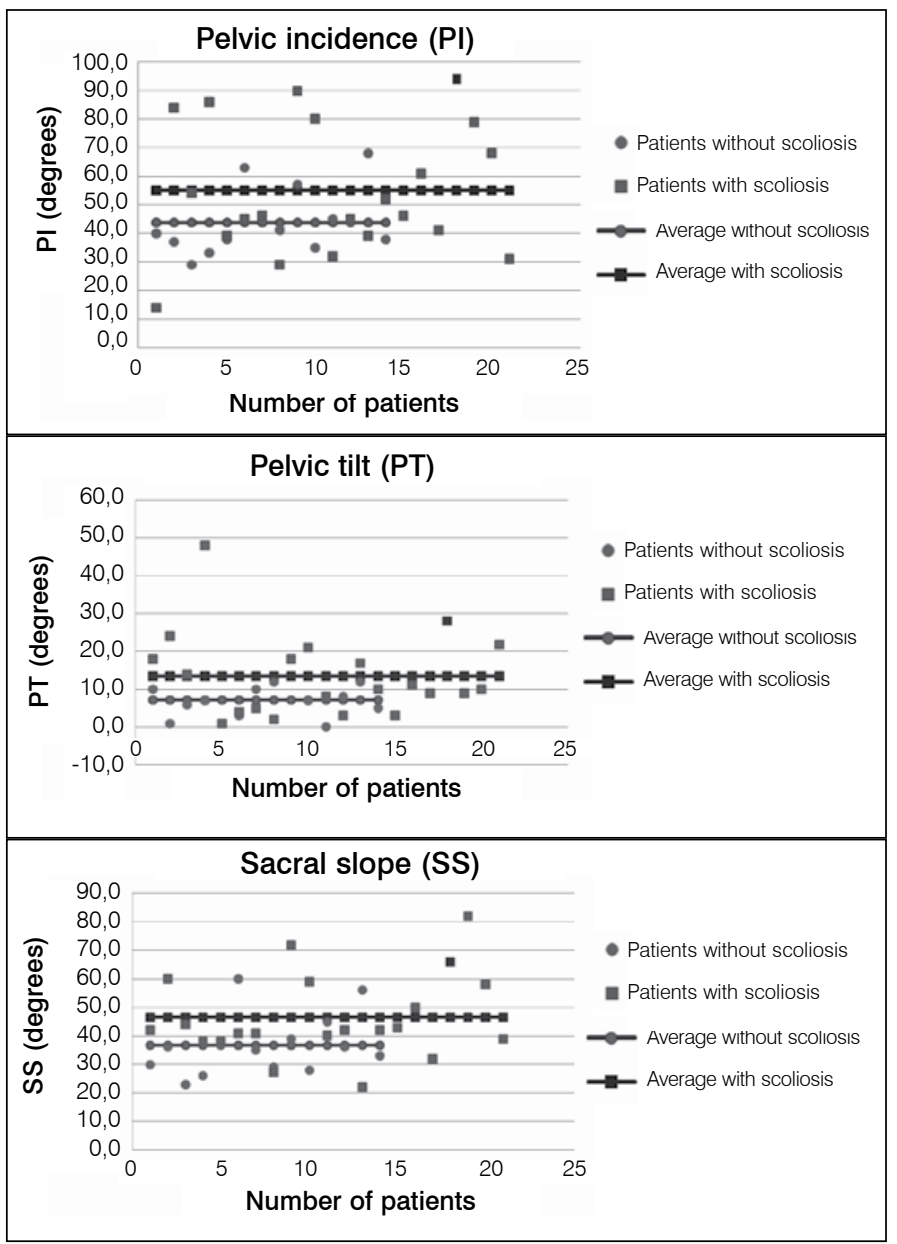

Figure 2. Averages of normal patients and patients with scoliosis.

Table 2. Comparison with the values from the study by Mac-Thiong et al. ${ }^{13}$

\begin{tabular}{c|c|c|c|c}
\hline Parameters & Average & \multicolumn{3}{|c}{ (Mac-Thiong JM et a) $\mathbf{1}^{\mathbf{3}}$} \\
\hline & & Women & Men & Average \\
\hline PI & $43.8( \pm 24.2)$ & $52.4( \pm 10.8)$ & $52.7( \pm 10)$ & 52.55 \\
\hline PT & $7.1( \pm 10.9)$ & $12.7( \pm 7)$ & $13.4( \pm 6.7)$ & 13.05 \\
\hline SS & $36.6( \pm 23.4)$ & $39.8( \pm 7.9)$ & $39.3( \pm 8)$ & 39.55 \\
\hline SSA & $135.6( \pm 20.4)$ & & & $134( \pm 8.1)$ \\
\hline SI & $95.1( \pm 16.9)$ & & & $90.8( \pm 34)$ \\
\hline SP & $4.3( \pm 16.7)$ & & & $0.1( \pm 1.9)$ \\
\hline L & $61.6( \pm 30.4)$ & -------- & & \\
\hline K & $27.6( \pm 21.6)$ & ------- & & \\
\hline PL & $-1.3( \pm 4)$ & & & \\
\hline
\end{tabular}

PI: pelvic incidence. PT: pelvic tilt, SS: sacral slope, SSA: spino-sacral angle, SI: spinal inclination, SP: S1 projection, L: lordosis, K: kyphosis, PL: plumb line. -------- not measured in this study. thology and a decrease in lordosis in comparison with the average, without statistical significance $(p=0.6)$, perhaps a result of the fact that the degree and rotation of the curve in each individual were not taken into account and because only 21 adolescents, a small $n$, with Lenke type 1 and 5 curves were used. The Student's t-test did not demonstrate statistical significance between the normal patients and those with scoliosis when these parameters were assessed. A follow-up to this study with a similar objective could explain this difference.

Vrtovec et al $^{15}$ published a review article in which they evaluated quantitative parameters of pelvic sagittal balance. They found that there was a good deal of ambiguity among the pelvic parameters analyzed in patients without pathology and even more in patients with spinal pathology. They made reference to $\mathrm{PI}$, a highly studied parameter and key to the sagittal alignment complex of the spine, which tends to increase with age in individuals both with and without scoliosis and decline in individuals with spondylolysis and spondylolisthesis. They concluded that normative values for the pelvic sagittal alignment parameters do not exist, as the variability among measured values is too high in normal individuals, but can be predictive for spinal alignment in several specific pathologies. Our study also shows a large variance for PI (43.8 \pm 24.2$)$ in normal patients and (55 \pm 41 ) in patients with scoliosis, demonstrating that the disease caused both an increase in the average of PI and an increase in the variance, and suggesting a change in sagittal balance, which was not proven by the Student's t-test $(\mathrm{p}<0.05)$, but, indirectly, in that PI $=\mathrm{PT}+$ SS and both PT and SS were statistically significant in the Student's t-test with $p<0.05$, we observed that there is a strong tendency to believe that scoliosis causes changes in the PI.

Many authors criticize use of the $p$-value ${ }^{16,17}$ for comparison of averages in medical research because the measurement and interpretation of a $p$-value can be highly influenced by sample size. Large samples can produce small p-values demonstrating statistical significance that does not exist, and small samples can yield large p-values, even when there is a great effect from a practical perspective. ${ }^{18}$ In this case, graphic evaluation becomes important in order to achieve more precise results.

\section{CONCLUSION}

Our study demonstrated that AIS of Lenke classification types 1 and 5 causes changes with statistical significance for two of the sagittal balance parameters evaluated, PT and SS. It also suggests that the pathology causes changes in all the other sagittal balance parameters. We also obtained results for the normal individuals similar to those found in the study previously conducted. We conclude by emphasizing the need for both follow-up and to conduct new studies that demonstrate these changes, evaluating sex, degree and severity of the curve, and taking lumbar and sagittal modifiers into consideration, and a study with a larger $\mathrm{n}$ so that no properties are lost as a result of dispersed samples.

All authors declare no potential conflict of interest concerning this article.

\section{REFERÊNCIAS}

1. Berthonnaudé, Dimnet $J$, Roussouly $P$, et al. Analysis of the sagittal balance of the spine and pelvis using shape and orientation parameters. J Spinal Disord Tech. 2005;18:40-7.

2. Boulay $C$, Tardieu $C$, Hecquet J, et al. Sagittal alignment of spine and pelvis regulated by pelvic incidence: standard values and prediction of lordosis. Eur Spine J. 2006;15:415-22.

3. Cil A, Yazici M, Uzumcugil A, et al. The evolution of sagittal segmental alignment of the spine during childhood. Spine. 2004;30:93-100.

4. Gelb De, Lenke LG, Bridwell KH, et al. An analysis of sagittal spinal alignment in 100 asymptomatic middle and older aged volunteers. Spine. 1995; 20:1351-8.

5. Hammerberg EM, Wood KB. Sagittal profile of the elderly. J Spinal Disord Tech. 2003;16:44-50.

6. Jackson RP, Phipps T, Hales $\mathrm{C}$, et al. Pelvic lordosis and alignment in spondylolisthesis. Spine. 2003:28:151-60.

7. Mac-Thiong JM, Labelle H, Berthonnaud E', et al. Sagittal spinopelvic balance in normal children and adolescents. Eur Spine J. 2007;16:227-34.

8. Vedantam R, Lenke LG, Keeney JA, et al. Comparison of standing sagittal spinal alignment in asymptomatic adolescents and adults. Spine. 1998:23:211-5.

9. Vialle R, Levassor N, Rillardon L, et al. Radiographic analysis of the sagittal alignment and balance of the spine in asymptomatic subjects. J Bone Joint Surg Am. 2005;87:260-7.

10. Henneman SA, Antoneli PHL, Oliveira GC, Incidência Pélvica: Um parâmetro fundamental para definição do Equilibrio Sagital da Coluna vertebral. Coluna/Columna. 2012; 11 (3): 237-9. 11. Kouwenhoven J-WM, Castelein RM, The Pathogenesis of Adoloscent Idiopathic Scoliosis. Spine 2008:33:2898-2908.

12. Lenke LG, Edwards CC, Bridwell KH, The Lenke Classification of Adolescent Indiopathic Scoliosis: How it Organizes Curve Patterns as a Template to Perform Selective Fusions of the Spine. 2003;28:S199-S207.

13. Mac-Thiong JM, Roussouly P, Berthonnaud É, Guigui P, Sagittal Parameters of Global Spinal Balance. Spine 2010;35:E1193-E1198.

14. Roussouly P, Lavelle H, Rouissi J, Bodin A, Pre- and post-opertive sagittal balance in idiopathic scoliosis: a comparison over the ages of two cohorts of 132 adolescents and 52 adults. Eur Spine J. 2012 nov 28.ods.

15. Vrtovec $T$, Janssen MM, Likar B, Castelein RM, Viergever MA, Pernus F, A review of methods for evaluating the quantitative parameters of sagittal pelvic alignment. Spine J. 2012 May; 12(5):433-46

16. Altman DG, Bland JM. Absence of evidence is not evidence of absence. British Medical Journal . 1995; 311:485.

17. Grimes DA, Schulz KF. An overview of clinical research: the lay of the land. The Lancet. 2002; 359:57-61.

18. Gardner MJ, Altman DG. Confidence intervals rather than $P$ values: estimation rather than hypothesis testing. British Medical Journal (Clin Res Ed). 1986;292(6522):746-50 